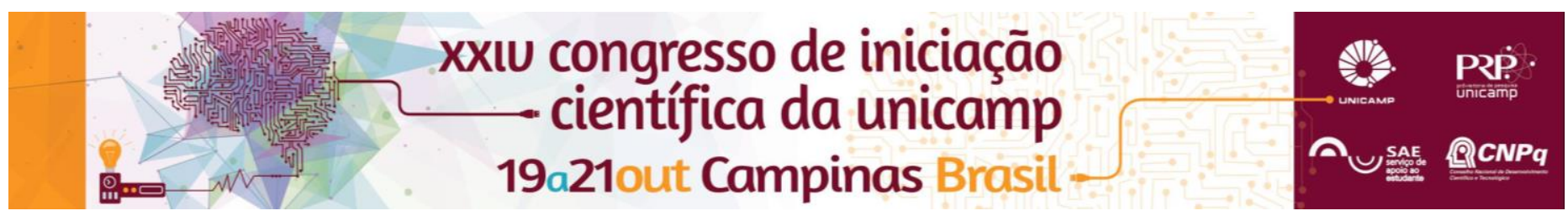

\title{
O material didático no ensino de língua inglesa no ProFIS e no CEL.
}

\section{Angélica R. Costa}

\begin{abstract}
Resumo
A língua Inglesa utilizada em meios acadêmicos ganhou mais destaque com o processo de internacionalização das universidades, fato que propicia oportunidades acadêmicas diversas como, por exemplo, a possibilidade de intercâmbio. Isso significa uma crescente demanda pelo conhecimento da língua inglesa. Entretanto, a aprendizagem desta língua é um processo complexo que requer a mobilização de habilidades linguístico - discursivas e envolve vários aspectos, tais como histórico, político, cultural, etc. Além da qualificação e atuação do docente, há a necessidade de um material didático que se inclua em novos contextos de ensino-aprendizagem dessa língua. Desta forma, os materiais didáticos ganham relevância, pois além de abarcar as particularidades da língua, devem ainda salientar aspectos culturais, visando a interculturalidade e promover o contato com textos multimodais que favoreçam a inserção do aluno na língua a ser aprendida. O objetivo principal desta pesquisa é analisar algumas atividades propostas nos materiais didáticos presentes em duas disciplinas distintas: Inglês II do Centro de ensino de línguas (CEL) e Língua Inglesa II do Programa de Formação Interdisciplinar Superior (ProFIS). Para tanto, pretende - se: a) descrever os dois materiais utilizados em seus contextos e b) identificar atividades que colaborem para um posicionamento crítico em cada material. Entendemos material didático em sua natureza multimodal (GEE, 1999), a qual abrange distintas formas - linguagem escrita, oral e/ou visual - e seus modos de representação utilizados na construção de um texto. Como metodologia, será apresentada uma revisão bibliográfica visando autores que discutam sobre materiais didáticos (ROCHA, 2013) e reflitam acerca dos conceitos de interculturalidade (MAHER, 2007) e estereótipos (KAWACHI,2015). Tais conceitos servirão de subsídios para análise dos materiais usados nas duas propostas de ensino e suas inserções em contextos específicos. A análise será encaminhada a partir de fragmentos do livro "American English File, Second Edition" 2013, utilizado na disciplina Inglês 2 do CEL, e o material usado e elaborado pelos professores do CEL para o ProFIS na disciplina LA092 ministrada no segundo semestre de 2015. Assim, esta pesquisa se propõe a realizar uma reflexão sobre o modo pelo qual os materiais didáticos incidem sobre aspectos culturais durante o processo de ensino/aprendizagem da língua Inglesa.
\end{abstract}

\section{Palavras-chave:}

Material didático; interculturalidade; estereótipo.

\section{Introdução}

Com 0 processo de Internacionalização das Universidades, a Língua Inglesa passou a ter uma grande importância na vida acadêmica, propiciando oportunidades diversas. Isto fez com que a procura pelo conhecimento da língua aumentasse e, neste sentido, o professor precisa se apoiar em materiais didáticos capazes de se inserirem em novos contextos educacionais. Focando em duas disciplinas ministradas na Universidade Estadual de Campinas, o objetivo desta pesquisa é analisar trechos de diferentes propostas de materiais utilizadas para o ensino-aprendizagem da língua inglesa, bem como a maneira que aspectos culturais, interculturais e estereótipos são tratados nas referidas propostas.

\section{Resultados e Discussão}

A pesquisa fará uma revisão bibliográfica com autores que tratem sobre materiais didáticos (ROCHA, 2013) interculturalidade (MAHER, 2007) e estereótipos (KAWACHI, 2015), a fim de analisar os materiais e suas inserções em contextos específicos. A pesquisa está em andamento, logo, ainda não se há resultados concretos obtidos.

\section{Conclusões}

Não há conclusões preliminares, uma vez que as análises estão sendo realizadas. 